\title{
Renal Pelvis and Ureter Cancer pT3 TNM
}

\section{Finding v8}

National Cancer Institute

\section{Source}

National Cancer Institute. Renal Pelvis and Ureter Cancer pT3 TNM Finding v8. NCI

Thesaurus. Code C140346.

For renal pelvis only: Tumor invades beyond muscularis into peripelvic fat or into the renal parenchyma. For ureter only: Tumor invades beyond muscularis into periureteric fat.

(from AJCC 8th Ed.) 